\title{
The Elements of Teachers' Competency for Creative Teaching in Mathematics
}

\author{
Azhari Mariani $^{1} \&$ Zaleha Ismail $^{1}$ \\ ${ }^{1}$ Department of Educational Science, Mathematics and Creative Multimedia, Faculty of Education, Universiti \\ Teknologi Malaysia, Johor Bharu, Johor, Malaysia \\ Correspondence: Azhari Mariani, Department of Educational Science, Mathematics and Creative Multimedia, \\ Faculty of Education, Universiti Teknologi Malaysia, Johor Bharu, Johor, Malaysia.
}

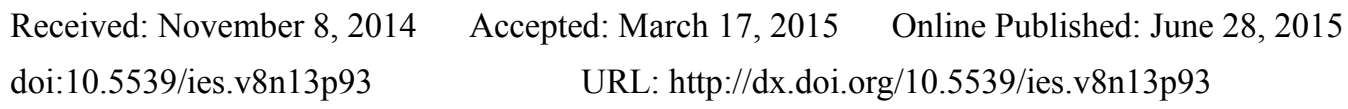

\begin{abstract}
Creative teaching in mathematics based on teachers' competency is important in helping to realize the objectives of the quality of education that is to be in the third position in international assessments such as Program for International Student Assessment (PISA) and Trends in Mathematics and Science Study (TIMSS). This study aims to explore and determine the elements of teachers' competency for creative teaching in mathematics which will be used as the measured variables and the basis for the construction of instruments in the process of developing a model of creative teaching in mathematics based on teachers' competencies. In order to identify the elements of teachers' competency, a qualitative exploratory study was conducted in the form of document analysis, literature analysis and experts interviews. Document analysis and literature analysis were analyzed using systematic data analyses, while the findings from the interviews were analyzed using a frequency matrix table. The findings of the study showed that the Professional Knowledge, Functionality Skills and Creative Attitudes were identified as the critical elements of teachers' competency for creative teaching in mathematics.
\end{abstract}

Keywords: exploratory, creative teaching, competency, mathematics, teachers' competency

\section{Introduction}

Creative teaching in mathematics based on teachers' competency is important in helping to realize the objectives of the quality of education that is to be in the third position in international assessments such as Program for International Student Assessment (PISA) and Trends in Mathematics and Science Study (TIMSS). This study aims to explore and determine the elements of teachers' competency for creative teaching in mathematics which will be used as the measured variables and the basis for the construction of instruments in the process of developing a model of creative teaching in mathematics based on teachers' competencies.

Creative teaching can be defined as a process of knowledge construction that is unique and meaningful in the context of learning (Rinkevich, 2011). This process refers to the role of the teacher as the person responsible for guiding students in constructing knowledge. Teaching is said to be creative when the teachers combine existing knowledge in new or unique approaches or introduce new processes to foster thought to produce good results (Reilly, Lilly, Bramwell, \& Kronish, 2011; Sale, 2005). According to Lou and Chen (2012), through creative teaching, the teachers act and apply suitable and flexible techniques in creating an exciting learning environment and help to develop the creative skills of the students.

In fact, creative teaching should be based on whether the teachers' competency are expressed outwardly or not inapparently. Based on Iceberg Competency Model (L. Spencer \& S. Spencer, 1993), the elements of competency are knowledge, skills, attitudes, personalities and values. Hence, according to Koster and Dengerink (2008), teachers' competency is a combination of knowledge, skills, attitudes, values and individuals' characteristics that empower teachers to act in a professional and appropriate manner in a particular situation and the overall deployment.

In associating teachers' competency with creative teaching, Sale (2005) defines creative teaching based on teachers' competency as their abilities to integrate knowledge, skills and attitudes through a combination of existing knowledge in new or unique approaches to produce good results. Thus, in the context of creative teaching in mathematics, the integration of competency elements such as knowledge, skills and attitudes is 
considered to be very important elements and a benchmark for teachers' competency. It means that teachers who are knowledgeable in creative teaching but have less skill to apply this knowledge are yet to be competent in the true sense.

Despite the efforts undertaken by the Ministry of Education (MOE) to improve the competence of teachers in the teaching of creative mathematics education with the provisions of funds such as a complete school infrastructure, provision of sophisticated computer labs, professional development for teachers and the creation of curriculum that emphasizes the creative process (Ministry of Education [MOE], 2012), many researchers have found that teachers' competency in implementing creative teaching in mathematics to be far from satisfactory (Lim, Fatimah, \& Tan, 2002; Rinkevich, 2011; Effandi \& Zanaton, 2007; Rychen \& Salganik, 2003) and resulted in students becoming less creative through the learning process.

Consequently, the quality of students' achievement in mathematics in Malaysia is found to be low and has not reached the expected standards and become an issue that is often debated at the national level. Majority of the students found to be less creative in solving mathematical problems. Evidence of this is shown by the poor results of Malaysia in international assessments such as the Trends in Mathematics and Science Study (TIMSS) and the Programme for International Student Assessment (PISA) (MOE, 2012). To overcome this problem, teachers need to be creative and competency aspects should be given attention in order to improve teaching performance. This study therefore aims to explore and determine the elements of teachers' competency for creative teaching in mathematics which will be used as the measured variables and the basis for the construction of instruments in the process of developing a model of creative teaching in mathematics based on teachers' competency.

\section{Method}

In order to identify the elements of teachers' competency, a qualitative exploratory study was conducted in the form of document analysis, literature analysis and experts interviews. Document analysis and literature analysis were analyzed by using systematic data analyses, while the findings from the interviews were analyzed by using a frequency matrix table. The selection of five literatures and five documents were based on five key elements of competency mentioned by L. Spencer and S. Spencer (1993) in his Iceberg Competency Model which consists of knowledge, skills, attitudes, personalities and values. Five experts in mathematics education were involed in semi-structured interviews consisting of an inspector from the Division of Planning and Research, Ministry of Education, a mathematics curriculum officer from the Curriculum Development Division, Ministry of Education, an excellent mathematics teacher from a secondary school and two higher institution mathematics lecturers.

\section{Results}

\subsection{Finding of Literature Analysis}

Finding as indicated in Table 1 is based on the literature analysis, which has been discussed by previous researchers. Among the related studies were conducted by Feiman-Nemser (2001), Rychen and Salganik (2003), Crawford (2005), Koster and Dengerink (2008) and McDiarmid and Bright (2008).

Table 1. Comparison of teachers' competency elements for creative teaching in mathematics based on the literature analysis

\begin{tabular}{|c|c|c|c|c|c|c|}
\hline No. & $\begin{array}{l}\text { Teachers' } \\
\text { Competency } \\
\text { Elements }\end{array}$ & $\begin{array}{c}\text { Feiman-Nemser } \\
\text { (2001) }\end{array}$ & $\begin{array}{c}\text { Rychen \& } \\
\text { Salganik } \\
\text { (2003) }\end{array}$ & $\begin{array}{l}\text { Crawford } \\
(2005)\end{array}$ & $\begin{array}{c}\text { Koster \& } \\
\text { Dengerink } \\
\text { (2008) }\end{array}$ & $\begin{array}{l}\text { McDiarmid \& } \\
\text { Bright (2008) }\end{array}$ \\
\hline 1. & $\begin{array}{l}\text { Professional } \\
\text { Knowledge }\end{array}$ & $X$ & $\mathrm{X}$ & $\mathrm{X}$ & $\mathrm{X}$ & $\mathrm{X}$ \\
\hline 2. & $\begin{array}{l}\text { Functionality } \\
\text { Skills }\end{array}$ & $X$ & $\mathrm{X}$ & $\mathrm{X}$ & $\mathrm{X}$ & $\mathrm{X}$ \\
\hline 3. & Creative Attitudes & $X$ & $X$ & $\mathrm{X}$ & $\mathrm{X}$ & $X$ \\
\hline 4. & Personalities & $\mathrm{X}$ & & & $\mathrm{X}$ & \\
\hline 5. & Values & & & & X & \\
\hline
\end{tabular}


Based on the literature analysis, the researchers have compiled a list of the key elements that are frequently mentioned by many previous researchers as teachers' competency elements for creative teaching in mathematics. The elements are professional knowledge, functionality skills, creative attitudes, personalities and values.

\subsection{Finding of Document Analysis}

Finding as indicated in Table 2 is based on the document analysis. Among the documents are Interim Strategic Plan 2011-2020, UNESCO ICT Competency Framework for Teachers (2011), Creativity Guide Book (2011), Malaysian Teacher Standards (2009) and Malaysia Education Blueprint 2013-2025 (2013).

Table 2. Comparison of teachers' competency elements for creative teaching in mathematics based on the document analysis.

\begin{tabular}{llccccc}
\hline No. & $\begin{array}{l}\text { Teachers' } \\
\text { Competency } \\
\text { Elements }\end{array}$ & $\begin{array}{c}\text { Interim } \\
\text { Strategic Plan } \\
2011-2020\end{array}$ & $\begin{array}{c}\text { UNESCO ICT } \\
\text { Competency } \\
\text { Framework for } \\
\text { Teachers }\end{array}$ & $\begin{array}{c}\text { MOE } \\
\text { Malaysia } \\
\text { Creativity } \\
\text { Guide Book }\end{array}$ & $\begin{array}{c}\text { Malaysian } \\
\text { Teacher } \\
\text { Standards }\end{array}$ & $\begin{array}{c}\text { Malaysia } \\
\text { Education } \\
\text { Blueprint } \\
2013-2025\end{array}$ \\
\hline 1. & $\begin{array}{l}\text { Professional } \\
\text { Knowledge }\end{array}$ & $\mathrm{X}$ & $\mathrm{X}$ & $\mathrm{X}$ & $\mathrm{X}$ & $\mathrm{X}$ \\
2. & $\begin{array}{l}\text { Functionality } \\
\text { Skills }\end{array}$ & $\mathrm{X}$ & $\mathrm{X}$ & $\mathrm{X}$ & $\mathrm{X}$ & $\mathrm{X}$ \\
3. & $\begin{array}{l}\text { Creative } \\
\text { Attitudes }\end{array}$ & $\mathrm{X}$ & & $\mathrm{X}$ & $\mathrm{X}$ & $\mathrm{X}$ \\
4. & $\begin{array}{l}\text { Personalities } \\
\text { 5. }\end{array}$ & & & $\mathrm{X}$ & $\mathrm{X}$ & $\mathrm{X}$ \\
\hline
\end{tabular}

Based on the analysis of the documents, the researchers have compiled a list of the key elements that are frequently mentioned in many documents for teachers' competency. The elements are professional knowledge, functionality skills, creative attitudes, personalities and values.

\subsection{Finding of Experts Interviews}

Finding as indicated in Table 3 is based on the experts interviews. It shows the differences in opinion towards the elements of competency that teachers need to possess in implementing creative teaching in mathematics.

Table 3. Comparison of teachers' competency elements for creative teaching in mathematics based on the experts interviews

\begin{tabular}{|c|c|c|c|c|c|c|}
\hline No. & $\begin{array}{l}\text { Teachers' Competency } \\
\text { Elements }\end{array}$ & Expert 1 & Expert 2 & Expert 3 & Expert 4 & Expert 5 \\
\hline 1. & $\begin{array}{l}\text { Professional } \\
\text { Knowledge }\end{array}$ & $\mathrm{X}$ & $\mathrm{X}$ & $\mathrm{X}$ & $\mathrm{X}$ & $\mathrm{X}$ \\
\hline 2. & Functionality Skills & $\mathrm{X}$ & $\mathrm{X}$ & $\mathrm{X}$ & $\mathrm{X}$ & $\mathrm{X}$ \\
\hline 3. & Creative Attitudes & $\mathrm{X}$ & $\mathrm{X}$ & & $\mathrm{X}$ & $\mathrm{X}$ \\
\hline 4. & Personalities & & $\mathrm{X}$ & & $\mathrm{X}$ & \\
\hline 5. & Values & $\mathrm{X}$ & & $X$ & & \\
\hline
\end{tabular}

Based on the experts' interviews, the researchers have compiled a list of the key elements that are frequently mentioned by experts for teachers' competency. The elements are professional knowledge, functionality skills, creative attitudes, personalities and values.

\section{Discussion}

The exploration of teachers' competency elements for creative teaching in mathematics was carried out in three ways: through analysis of literature, analysis of documents and also through oral interviews of experts in the 
field of mathematics education. The literature analyzed included were printed books, articles in journals and seminar working papers. Among the related studies were conducted by Feiman-Nemser (2001), Rychen and Salganik (2003), Rinkevich (2011), Crawford (2005), Koster and Dengerink (2008) and McDiarmid and Bright (2008).

The documents studied were guide books, teachers' standard, competency frameworks and education policies. Among the related documents referred to Interim Strategic Plan 2011-2020, UNESCO ICT Competency Framework for Teachers (2011), Creativity Guide Book (2011), Malaysian Teacher Standards (2009) and Malaysia Education Blueprint 2013-2025 (2013).

The teachers' competency elements: professional knowledge, functionality skills, creative attitudes, personalities and values are the key elements that are frequently mentioned in the literature and documents as well as from the views of the experts in the field and relevant for teachers' competency elements for creative teaching in mathematics. However, after triangulation of three sources ( literature, documents and expert analysis), the three key elements converged at professional knowledge, functionality skills and creative attitudes which are the most mentioned elements of teachers' competency for creative teaching in mathematics as shown in Figure 1. These elements were identified as the critical elements of teachers' competency for creative teaching in mathematics of the study. This finding support the result from study by Sale (2005) who defines creative teaching based on teachers' competency as their abilities to integrate knowledge, skills and attitudes through a combination of existing knowledge in new or unique approaches to produce good results. This finding also showed that personalities and values are relevant but not critical to be the elements of teachers' competency for creative teaching in mathematics.

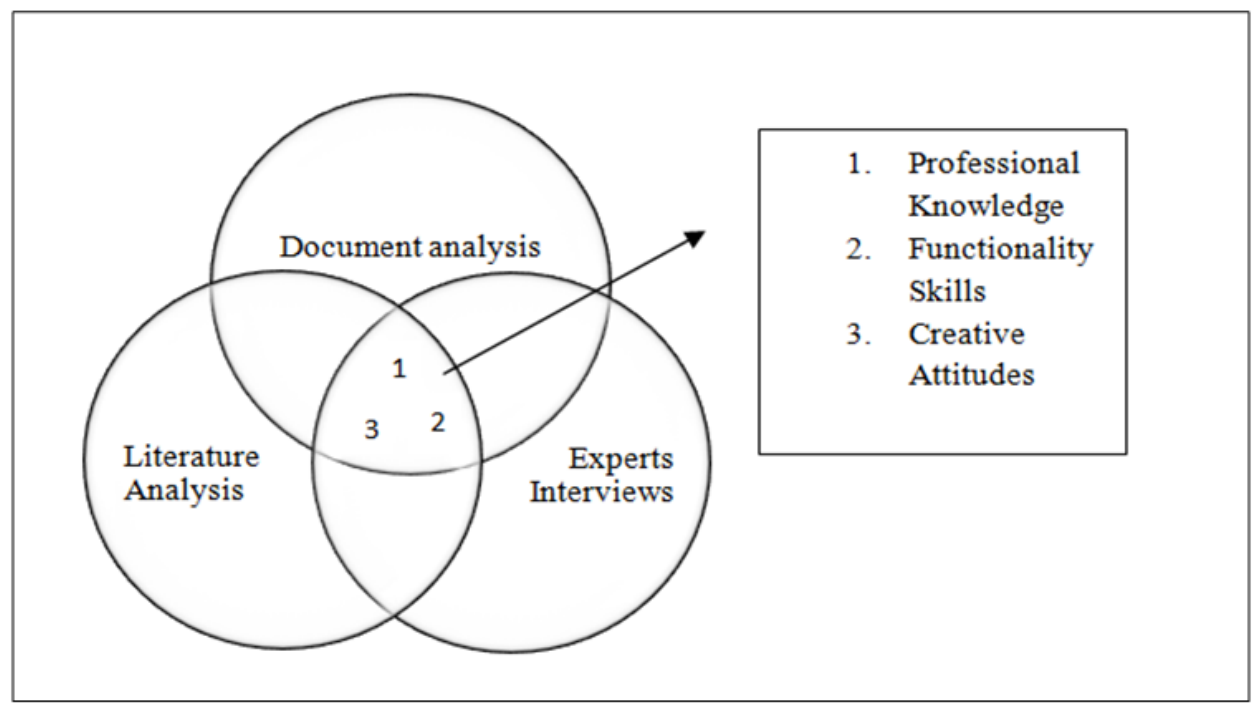

Figure 1. The elements of teachers' competency for creative teaching in mathematics

\section{Conclusion}

In this study, teachers' competency elements were identified based on literature analysis, document analysis and interviews with experts. The profesional knowledge, functionality skills, creative attitudes, personalities and values are frequently mentioned as the elements of teachers' competency but the most frequently mentioned are profesional knowledge, functionality skills and creative attitudes. Hence, based on the findings of this study, the researchers concluded that the professional knowledge, functionality skills and creative attitudes were identified as the critical elements of teachers' competency for creative teaching in mathematics.

\section{Acknowledgements}

We would like to acknowledge Ministry of Education of Malaysia and Universiti Teknologi Malaysia (UTM) with the Grant vot number Q.J130000.2531.05H73 for the financial support of this paper. 


\section{References}

Crawford, L. (2005). Senior mamagement perceptions of project management competence. International Journal of Project Management, 23(1), 7-16. http://dx.doi.org/10.1016/j.ijproman.2004.06.005

Effandi, Z., \& Zanaton, I. (2007). Promoting Cooperative Learning in Science and Mathematics Education: A Malaysian Perspective. Eurasia Journal of Mathematics, Science \& Technology Education, 3(1), 35-39.

Feiman-Nemser, S. (2001). From preparation to practice: designing a continuum to strengthen and sustain teaching. Teachers College Record, 103(6), 1013-1055. http://dx.doi.org/10.1111/0161-4681.00141

Koster, B., \& Dengerink, J. J. (2008). Professional standards for teacher educators: How to deal with complexity, ownership and function. Experiences from the Netherlands. European Journal of Teacher Education, 31(2), 135-149. http://dx.doi.org/10.1080/02619760802000115

Lim, C. S., Fatimah, S., \& Tan, S. K. (2002). Cultural influences in teaching and learning of mathematics: Methodological challenges and constraints. In D. Edge, \& B. H. Yeap (Eds.), Proceedings of Second East Asia Regional Conference on Mathematics Education and Ninth Southeast Asian Conference on Mathematics Education, 1, 138-149.

Lou, S., \& Chen, N. (2012). Using blended creative teaching: Improving a teacher education course on designing materials for young children. Australasian Journal of Educational Technology, 28(5), 776-792.

McDiarmid, W. G., \& Bright C. M. (2008). Rethinking Teacher Capacity. In M. Cochran-Smith, S. Feiman-Nemser, \& D. McIntyre (Eds.), Handbook of Research on Teacher Education. Enduring questions in changing contexts. New York/Abingdon: Routledge/Taylor \& Francis.

Ministry of Education Malaysia. (2011). Buku Panduan Kreativiti (Creativity Guide Book): Pembangunan dan Amalan dalam pengajaran dan pembelajaran. Bahagian Pembangunan Kurikulum.

Ministry of Education Malaysia. (2012). Interim Strategic Plan, Ministry of Education Malaysia, 2011-2020.

Ministry of Education Malaysia. (2013). Malaysia Education Blueprint 2013-2025.

Ministry of Education. (2009). Malaysian Teacher Standards. Division of Teacher Education.

Reilly, R. C., Lilly, F., Bramwell, G., \& Kronish, N. (2011). A synthesis of research concerning creative teachers in a Canadian context. Teaching and Teacher Education, 27(3), 533-542. http://dx.doi.org/10.1016/j.tate.2010.10.007

Rinkevich, J. L. (2011). Creative Teaching: Why it Matters and Where to Begin. The Clearing House: A Journal of Educational Strategies, Issues and Ideas, 84(5), 219-223. http://dx.doi.org/10.1080/00098655.2011.575416

Rychen, D. S., \& Salganik, L. H. (2003). Key Competencies for a successful life and a well-functioning society. Göttingen: Hogrefe \& Huber.

Sale, D. (2005). De-mystifying Creative Teaching Competence. In paper presented at the international conference on Redesigning Pedagogy: Research, Policy, Practice held at National Institute of Education, Nanyang Technological University (pp. 1-9).

Spencer, L. M., \& Spencer, S. M. (1993). Competence at work models for superior performance. John Wiley and Sons Inc.United States of America.

Tengku, Z. T. Z. (2005). Pengetahuan Pedagogi Isi Kandungan Bagi Tajuk Pecahan Di Kalangan Guru Matematik Sekolah Rendah (Thesis of doctorate of philosophy, Universiti Kebangsaan Malaysia).

UNESCO. (2011). Unesco ICT Competency Framework for Teachers. United Nations Educational, Scientific and Cultural Organization: Paris.

Zaleha, I., \& Nurul, L. A. (2011). Pengaruh Gaya Kognitif dan Kreativiti Terhadap Penyelesaian Masalah Geometri Di Kalangan Pelajar Tingkatan 4 Aliran Sains. Journal of Science and Mathematics Educational, $3(1), 46-66$.

\section{Copyrights}

Copyright for this article is retained by the author(s), with first publication rights granted to the journal.

This is an open-access article distributed under the terms and conditions of the Creative Commons Attribution license (http://creativecommons.org/licenses/by/3.0/). 